\title{
Legumes Consumption among Young and Adult Residents In Sicily (South Italy): Evidence and Predictive Factors
}

\author{
Fiore* M, Castiglione D, Ferrante M \\ Department "GF Ingrassia", University of Catania, Catania, Italy
}

Received: January 21, 2017; Accepted: February 02,2017; Published: February 27, 2017

*Corresponding author: Maria Fiore, PhD MD, Professor, Department "GF Ingrassia" Hygiene and Public Health, University of Catania, Catania, Italy, Via Santa Sofia 87, PO Box 95123, Catania, Italy, Tel.: +39-3782188; Fax: +39-3782177; E-mail: mfiore@unict.it

\begin{abstract}
Introduction: Despite the consumption of legumes is recommended by public health agencies around the world because of beneficial for health they tend to be consumed infrequently. This paper investigates the legumes consumption between young and adults resident in Sicily (south Italy) and explores its association with potential predictors.
\end{abstract}

Methods: A cross-sectional survey was conducted in 2015-2016. Participants were recruited into gyms and pediatrician's officers. Legumes consumption, socio-demographic variables, habits and lifestyle were evaluated using an anonymous questionnaire. To compare between group differences in all continuous or categorical variables, parametric or non-parametric test were appropriately used to test statistical significance. A logistic regression analysis was conducted in order to assess the role of the participant characteristics on the legumes consumption. The statistical significance was set to 0.05 .

Results: Participants were 561 (71\% females) aged 4-74 years (mean $35 \pm 16$ ). The "legume consumers" were less than $50 \%$. Our results indicate that, predictors supported by the greatest amount of evidence may be gender, age, education level, residence, marital status, occupation, weight status and physical activity. In particular the odds for greater legumes consumption increased for the subjects engage regular physical activity $(\mathrm{OR}=1.68 ; \mathrm{p}=0.019)$.

Conclusions: The legumes consumption was infrequent despite their positive health effects. Future studies are needed to increase knowledge about the reasons for the low consumption of legumes and to implement interventions and specific education about their healthy benefits.

\section{Introduction}

Legumes are the edible seeds of members of the Fabaceae (Leguminosae) family [1]. Legumes have been a staple food for many civilizations around the world for over 10.000 years. Their consumption dates back to as far as $5500 \mathrm{BC}$ and they are thought to be one first croups cultivated by people [2]. They are valued around the globe as an inexpensive alternative to meat
[3]. Humans have observed, over many centuries, that diets low in meat and high in cereals and legumes are beneficial for health. Epidemiological studies over the last 20 years have conformed these observations i.e that eating legumes can extend life by preventing chronic disease, including cardiovascular disease, coronary artery disease [4], diabetes, bowel cancer [5] and overweight as well as improving gut health $[6,7,8]$. The consumption of legumes is recommended by public health agencies around the world. The recommendation to consume legumes is based on them being a good source of protein, fiber, and several micronutrients including iron and zinc [9]. Despite these evidences the legumes tend to be consumed infrequently by many people resident in industrialized countries [9]. Their consumption in the western world remains quite low at less than 3-5 kg/capita for year. In other parts of the world, annual legumes consumption can range from $10 \mathrm{~kg} /$ capita (South America and India) to $40 \mathrm{~kg} /$ capita (Burundi) [1]. Simona Giampaoli et al. published an article describing foods consumed by middle-aged adults in 1960 in the town of Nicotera (Italy). According to this manuscript the legumes consumption was $43 \mathrm{~g} /$ day and $39 \mathrm{~g} /$ day for men and women, respectively. While the investigation food HES (Health examination survey), conducted on 1,968 men and 2,062 women in 2008-2012, aged 40-59 years, resident in all Italian regions the legumes consumption both for men and women was $22 \mathrm{~g} /$ day [10]. A cross-sectional study on 1065 medical students shows that only $35 \%$ eat legumes more than once a week [11].

Therefore the aims of the study were to investigate the legumes consumption among young and adults resident in Sicily (south Italy) and the predictive factors.

\section{Materials and methods}

We carried out a cross-sectional survey. This study was carried out in 2015-2016 in Sicily (South Italy). Participants were recruited, on a voluntary basis, into gyms and pediatricians. Data on socio-demographic variables, habits, lifestyle and legumes consumption were collected by an anonymous questionnaire. 
Underage's questionnaires were filled in by parents. Legumes consumption was evaluated by the question "Do you consume legumes more than one time/week?". All occupation categories were unified and compared with "unemployed" and "housewife categories". Alcohol consumption was evaluated by the question "Do you consume alcohol every day?" We considered smokers who reported to be smokers at the time of the interview or have stopped smoking less than six months. The height-weighers conditions of young people were assessed by BMI (Body Mass Index), using the thresholds calculated by Cacciari [12]. Children under 6 years were not recruited because lack the specific thresholds for estimating height-weighers conditions. Underweight children have been incorporated in the normal weight category.

\section{Statistical analysis}

Quantitative variables are presented as median and Interquartile interval (IQR) or mean \pm Standard Deviation (SD) and qualitative ones through frequencies and percentages. The sample was categorized in consumers and non-consumers of legumes. To evaluate possible differences between these two groups Pearson's chi-square test for qualitative variables and Mann-Whitney U test for quantitative variables were performed. A logistic regression model was used to identify possible factors associated with legumes consumption. Statistical analysis was performed using the Statistical Package for the Social Science [SPSS], version 21.0 [SPSS Inc., Chicago, IL, USA]. The statistical significance was set to 0.05 .

\section{Results}

A total of 561 (71\% females) subjects aged between 4 and 74 years were recruited. Table 1 shows characteristics of the sample divided in legume consumers and not consumers. The "legume consumers" were $42.4 \%$, the legumes consumers are more likely to be women (71.8 vs. 28.2). Consumer legumes seem to increase with age and then decrease after 49 years. There is a greater frequency of residents in extra urban area of legumes consumers (63.6 vs 36.4). Consumer legumes seem to increase with the level of educational level to undergo a decrease in graduate subjects. The consumption of legumes is higher in married subjects. Among consumers of legumes than non-consumers there is a higher percentage of housewives (38.2 vs. 30.0). Among non-consumers of legumes there was a higher frequency of smokers and a lower daily alcohol consumption frequency. Among non-consumers of legumes more frequently occur overweight or obese subjects. Individuals that consume legumes more frequently performing regular physical activity (42.0 vs $30.1 ; \mathrm{p}=0.019$ ). Subjects who did not consume legumes more frequently had health problems. In the logistic regression model the odds for greater legumes consumption increased for the subjects engage regular physical activity (OR $=1.68 ; \mathrm{p}=0.019$ ).

\section{Discussion}

Less than $50 \%$ of the subjects were "legume consumers". In fact compared to the Sixties Mediterranean model, consumption of cereals, potatoes, and legumes are reduced by half [10].

Our results indicate that predictors supported by the greatest
Table 1: Sample's characteristics and comparison by legumes consumption. For dichotomous variables [yes/no], "yes" percentage was reported only.

\begin{tabular}{|c|c|c|c|c|}
\hline \multirow[t]{2}{*}{ Variables } & & \multicolumn{3}{|c|}{$\begin{array}{l}\text { Legumes consumption } \\
\text { [More than one time/week] }\end{array}$} \\
\hline & & $\begin{array}{c}\text { YES } \\
{[n=238]} \\
n \text { [\% column] }\end{array}$ & $\begin{array}{c}\text { No } \\
{[\mathrm{n}=323]} \\
\mathrm{n}[\% \\
\text { column] }\end{array}$ & p-value* \\
\hline Gender & & & & 0.538 \\
\hline & Males & 66 [28.2] & $98[30.6]$ & \\
\hline & Females & 168 [71.8] & 222 [69.4] & \\
\hline
\end{tabular}

\begin{tabular}{|c|c|c|c|c|}
\hline & Females & $168[71.8]$ & $222[69.4]$ & \\
\hline \multirow{2}{*}{ Age [years] } & & 39 & 39 & 0.12 \\
\hline \multirow{2}{*}{ Median[IQR] } & & {$[28-44]$} & {$[27-45]$} & \\
\hline & $<=21$ & $49[21.0]$ & $74[23.0]$ & 0.357 \\
\hline & $22-48$ & $152[65.2]$ & $192[59.6]$ & \\
\cline { 2 - 5 } & $49+$ & $32[13.7]$ & $56[17.4]$ & \\
\hline
\end{tabular}

\begin{tabular}{|l|c|c|c|c|}
\hline & $49+$ & $32[13.7]$ & $56[17.4]$ & \\
\hline Residence & \multicolumn{3}{|c|}{} & 0.147 \\
\hline & Urban area & $84[36.4]$ & $136[42.5]$ & \\
\cline { 2 - 5 } & $\begin{array}{c}\text { Extra urban } \\
\text { area }\end{array}$ & $147[63.6]$ & $184[57.5]$ & \\
\hline Education & \multicolumn{2}{|c|}{} & & \\
\hline
\end{tabular}

\begin{tabular}{|c|c|c|c|c|}
\hline \multirow[t]{6}{*}{ Education } & & & & 0.44 \\
\hline & $\begin{array}{l}\text { Elementary } \\
\text { school }\end{array}$ & $4[1.7]$ & $4[1.2]$ & \\
\hline & $\begin{array}{l}\text { Middle } \\
\text { school }\end{array}$ & $36[15.4]$ & 35 [10.9] & \\
\hline & Diploma & 100 [42.7] & 130 [40.4] & \\
\hline & Graduate & $48[20.5]$ & 79 [24.5] & \\
\hline & Students & 46 [19.7] & 73 [22.7] & \\
\hline \multirow[t]{5}{*}{ Marital status ${ }^{* *}$} & & & & 0.772 \\
\hline & Married & $166[87.4]$ & 211 [84.7] & \\
\hline & Single & $10[5.3]$ & $19[7.6]$ & \\
\hline & Divorced & $13[6.8]$ & $17[6.8]$ & \\
\hline & Widowed & $1[0.5]$ & $2[0.8]$ & \\
\hline \multirow{2}{*}{$\begin{array}{c}\text { Occupation [yes/ } \\
\text { no] }\end{array}$} & & 112 [58.6] & 169 [67.6] & 0.152 \\
\hline & Housewife & $73[38.2]$ & $75[30.0]$ & \\
\hline$\underset{\text { no] }}{\text { Smoking [yes/ }}$ & & 49 [25.7] & 65 [26.2] & 0.913 \\
\hline $\begin{array}{c}\text { Alcohol } \\
\text { consumption [yes/ } \\
\text { no] }\end{array}$ & & $44[23.7]$ & 55 [22.3] & 0.733 \\
\hline $\begin{array}{c}\text { BMI }[\mathrm{kg} / \mathrm{m} 2] \text { mean } \\
\pm \mathrm{SD}\end{array}$ & & $24 \pm 4$ & $24 \pm 4$ & 0.928 \\
\hline \multirow[t]{5}{*}{$\begin{array}{l}\text { BMI }[\mathrm{kg} / \mathrm{m} 2] \\
\text { category }\end{array}$} & & & & 0.683 \\
\hline & $\begin{array}{c}\text { Underweight } \\
{[<18.5]}\end{array}$ & $11[5.9]$ & $12[5.0]$ & \\
\hline & $\begin{array}{c}\text { Normal } \\
{[18.5-24.9]}\end{array}$ & $114[61.6]$ & $136[57.1]$ & \\
\hline & $\begin{array}{l}\text { Overweight } \\
{[25-29.9]}\end{array}$ & $52[28.1]$ & 76[31.9] & \\
\hline & Obese [>30] & $8[4.3]$ & $14[5.9]$ & \\
\hline $\begin{array}{l}\text { Regular physical } \\
\text { activity [yes/no] }\end{array}$ & & $63[42.0]$ & 66 [30.1] & 0.019 \\
\hline $\begin{array}{c}\text { Health problems } \\
\text { [yes/no] }\end{array}$ & & 31 [16.5] & 55 [22.4] & 0.123 \\
\hline
\end{tabular}


amount of evidence are gender, age, education level, residence, marital status, occupation, physical activity and weight status. Women tend to have amore frequent intake of legumes than men, and a corresponding pattern is seen for the younger age groups compared to the children while after 49 years it decreased. High prevalence of children who consumed less than one daily serving legumes; early feeding practices, parental education, and family incomeare associated with this process [13].Children's preference for fruit over vegetables appeared to be related to the sensory attributes of fruit and vegetables and to the way vegetables are prepared [14]. Benjamin W. Chaffee showed that in a cohort of children aged 6 to 10 years the frequency of consuming legumes trailed well behind that of soft drinks, sweets, cakes, and cookies for adolescents nationally. This is a complex problem, with deep roots in global economic forces that dictate the cost, accessibility, and marketing of healthy and unhealthy foods, as much as it is a question of consumer behavior and personal decision-making [15] or we think that legumes are labeled as food for the poor and therefore not considered as a meal in industrialized countries. A review shows that home availability, family rules (demand/ allow) and parental encouragement were positively associated with children's fruit and legumes consumption and that parental modelling and parental intake were positively associated with children's consumption of fruit and legumes. Legume consumers of our study frequently live in extra urban area according with others studies [16]. Rikke Krølner et al suggest that availability affected also by location/residence (rural/urban/reservation) [14]. There is also evidence for a positive association between education level and legumes intake [17], although graduates seem consume less legumes. Mothers' education level may be more important than fathers' ones for adolescent girls' eating behavior because mothers usually prepare meals, spend more time with the children and act as role models, especially for girls [18]. Elfhag and Linne [19] determine that eating pathology is shared by mothers and daughters, but not by sons. 'Overweight in parents' was relevant because among non-consumers of legumes were found more frequently obese or overweight subjects. Moreover numerous studies have shown that overweight in parents influences the child's eating behavior [18]. In our study individuals who practice physical activities consumed more frequently legumes, on the contrary smokers and alcohol consumers eating legumes less frequently. We have not found evidence in the literature; we hypothesize that who practice physical activities probably keep their self in shape more than smokers and alcohol consumers. Married people had higher intake than single. Carlijn B. M. Kamphuis et al. argues that being married (i.e. living together with a partner), compared with being single, can be viewed as a socio-environmental factor as the presence of a partner may affect a person's fruit and vegetable intake via the partner's eating patterns social support, sociocultural norms, home availability of fruit and vegetable [20]. The top three reasons reported for not eating legumes were: lack of knowledge of how to prepare them, a poor understanding of the health benefits and concern over side effects such us bloating and flatulence [21]. We think that the time limits for cooking legumes is an important determinant in accordance with our result that housewives were legume consumers more than other categories.
This study has limitations. We don't account of socioeconomic status. The study design was a cross-sectional survey thus it don't examine cause and effect but interrelationship. The sample size and the investigated area were limited.

\section{Conclusion}

In conclusion our findings highlight the need of future studies to investigate the attitudes, knowledge and beliefs affecting legumes consumption and the skill set to cook it. Finally, interventions and specific education about their healthy benefits may be useful to recover people's legume consumption as in the old eating tradition.

\section{References}

1. Mudryj AN, Yu N, Hartman TJ, Mitchell DC, Lawrence FR, Aukema HM. Br J Nutr. Pulse consumption in Canadian adults influences nutrient intakes. Br J Nutr. 2012;108(1):S27-36. doi: 10.1017/ S0007114512000724.

2. Messina MJ. Legumes and soybeans: overview of their nutritional profiles and health effects. Am J Clin Nutr. 1999;70:439S-450S.

3. Kouris-Blazos A, Belski R. Health benefits of legumes and pulses with a focus on Australian sweet lupins. Asia Pac J Clin Nutr. 2016;25(1):117. doi: 10.6133/apjen.2016.25.1.23.

4. Trowell HC. Crude fibre, dietary fibre and atherosclerosis. Atherosclerosis. 1972;16(1):138-140.

5. Burkitt DP. Epidemiology of cancer of the colon and rectum. Cancer 1971;29:3-13.

6. Kushi LH, Meyer KA, Jacobs JrDR. Cereals, legumes, and chronic disease risk reduction: evidence from epidemiologic studies. Am J Clin Nutr. 1999; 70(3 Supp):451S-458S.

7. Curran J. The nutritional value and health benefits of pulses in relation to obesity, diabetes, heart disease and cancer. Br J Nut. 2012;108:S1S2. doi: $10.1017 /$ S0007114512003534.

8. Trinidad TP, Mallillin AC, Loyola AS, Sagum RS, Encabo RR. The potential health benefits of legume as a good source of dietary fibre. Br JNutr. 2010;103(4):569-574.

9. Venn B, Thies F, O'Neil C. Whole grains, legumes, and health. J Nutr Metab. 2012;2012:903767. doi: 10.1155/2012/903767

10. Giampaoli S, Krogh V, Grioni S, Palmieri L, Gulizia MM, Stamler J, et al. Eating behaviours of italian adults:results of the Osservatorio epidemiologico cardiovascolare/ HealthExamination Survey. Epidemiol Prev. 2015;39(5-6):373-379.

11. Fiore M, Ledda C, Rapisarda V, Sentina E, Mauceri C, D’Agati P, et al. Medical school fails to improve Mediterranean diet adherence among medical students. Eur J Public Health. 2015;25(6):1019-1023. doi: 10.1093/eurpub/ckv127.

12. Cacciari E, Milani S, Balsamo A, Spada E, Bona G, Cavallo L, et al. Italian cross-sectional growth charts for height, weight and BMI (2 to $20 \mathrm{yr}$ ). J Endocrinol Invest. 2006;29(7):581-593.

13. Julia L. Valmórbidaa, Márcia R. Vitolo. Factors associated with low consumption of fruits and vegetables by preschoolers of low socioeconomic level. J Pediatr (Rio J). 2014;90(5):464-471.

14. Krølner R, Rasmussen M, Brug J, Klepp KI, Wind M, Due P. Determinants of fruit and vegetable consumption among children and adolescents: a review of the literature. Part II: qualitative studies. Int J Behav Nutr Phys Act. 2011;14(8):112. doi: 10.1186/1479-5868-8-112. 
15. Chaffee BW. Early life factors among the many influences of child fruit and vegetable consumption. J Pediatr (Rio J). 2014;90(5):437-43

9. doi: 10.1016/j.jped.2014.06.001

16. Rasmussen M, Krølner R, Klepp KI, Lytle L, Brug J, Bere E, et al Determinants of fruit and vegetable consumption among children and adolescents:a review of the literature. Part I: Quantitative studies. Int J Behav Nutr Phys Act. 2006;11(3)-22.

17.Pearson N, Biddle SJ, Gorely T. Family correlates of fruit and vegetable consumption in children and adolescents: a systematic review. Public Health Nutr. 2009;12(2):267-283. doi: 10.1017/ S1368980008002589.

18. Bau AM, Krull S, Ernert A, Babitsch B. Eating behaviour and its association with social living conditions and weight status among adolescent girls: results of the cross-sectional Berlin School Children's Cohort study. Public Health Nutr. 2011;14(10):1759-1767. doi: $10.1017 / \mathrm{S} 1368980011000541$.

19. Elfhag $\mathrm{K} \&$ Linne Y. Gender differences in associations of eating pathology between mothers and their adolescent off spring. Obes Res 2005;13:1070-1076.

20. Kamphuis CB, Giskes K, de Bruijn GJ, Wendel-Vos W, Brug J, van Lenthe FJ. Environmental determinants of fruit and vegetable consumption among adults: a systematic review. Br J Nutr. 2006;96(4):620-635

21. Go Grains Health \& Nutrition. The grains and legume health report. North Sydney NSW, Australia: Go Grain Health \& Nutrition Ltd. 2010. 